insights, sapped our energies and dispirited our determination to act.

And, most significantly, they have silenced all too many voices among those who are experiencing the epidemic in their own bodies and their own families and in their own communities. The deniers have re-created shame, and reimposed silence, in an epidemic where the struggle for twenty years has been to create voices and to defeat shame.

The denial of the facts about AIDS is not only an outrage against the truth. It is a profound insult to those South Africans who are living with and dying from the effects of the virus. They deny us the dignity of our suffering. They deny us the dignity of our struggle for life against the workings of a viral agent.

Most importantly, they deny us the dignity of the truth, and the power and hope, and the opportunities for action, that acceptance of the truth brings.

In countless villages and townships and cities and settlements in South Africa, where the virus is taking its toll of health and life among our people, the terrible truth about AIDS is being born and lived and died. Our people are being born, are living with, and dying from that truth. They are living that truth in the rising fevers, the wasting of flesh and the slow, agonised cessation of bodily functions that result from the virus.

Their suffering is being increased and is being prolonged incalculably by the deniers.

But, as we have seen today, from the terrible grief of those affected by the virus a terrible determination arises: a determination to defeat untruth and misrepresentation and distortion, and to assert hope.

That is the ultimate significance of the unforgettable images of this exhibition: that untruth and inaction are the greatest crimes of all. Let us take an angry inspiration, and a deep determination, from that.

REFERENCE

1. Hongwane C. Caravans, cats, geese, foot \& mouth and statistics - HIV/AIDS and the struggle for the humanisation of the African. ANC document, distributed April 2002.

\title{
FOCUS
}

\section{HIV/AIDS profile in the provinces of South Africa, 2002}

A booklet entitled HIV/AIDS Profile in the Provinces of South Africa: Indicators for 2002 has recently been released. It makes provincial trends and statistics on the HIV/AIDS epidemic available to government officials at all levels, as well as to business people, non-governmental organisations (NGOs) and the public. The report gives readers a sense of the magnitude of the numbers involved, and will allow them to benchmark other information about the epidemic as it becomes available.

The booklet can be downloaded from www.mrc.ac.za or www.assa.org.za/aidsmodel.asp or www.commerce.uct. ac.za/care, and is also available from the University of Cape Town (UCT)'s Centre for Actuarial Research at R30 per copy (tel. (021) 650-2475).

The estimates provided are not new - in fact, they have been available for the last year on the Actuarial Society of South Africa's website - but it is the first time they have been compiled into one publication for ease of access.

The indicators are based on a model constructed by the Actuarial Society of South Africa (ASSA). While there is always a degree of uncertainty surrounding such estimates, models can provide an invaluable tool for giving a sense of possible future scenarios. The ASSA model is continuously being improved as more data become available and our understanding of the dynamics of the epidemic improve.

Some of the information available in the report:

졸 The extent of the epidemic, with 6,5 million people ( $14,2 \%$ of the population) infected with HIV by July 2002.

Of these, over 95\% (6.1 million) are in the age group 18 - 64 years (labour force age).

The prevalence is highest (25.9\%) among young women of childbearing age - this, in turn, has implications in terms of numbers of orphans.

The prevalence of HIVIAIDS (among all ages) in each of the provinces is as follows:

$\begin{array}{llll}\text { KwaZulu-Natal } & 18.4 \% & \text { Eastern Cape } & 11.3 \% \\ \text { Free State } & 16.7 \% & \text { Limpopo } & 11.0 \% \\ \text { Mpumalanga } & 16.5 \% & \text { Northern Cape } 7.9 \% \\ \text { Gauteng } & 16.0 \% & \text { Western Cape } & 4.2 \% \\ \text { North West } & 15.1 \% & & \end{array}$


Making the epidemic more visible, and understanding its dynamics through such reports is important not only in managing the impact of the epidemic but also in eventually being able to turn the tide of it. For all spheres of planning, it is essential to have an understanding of where the country stands in terms of HIV/AIDS.
For further information contact:

Professor Rob Dorrington, UCT Centre for Actuarial Research

Tel. (021) 650-2467

Dr Debbie Bradshaw, MRC Burden of Disease Research Unit

Cell: 0824611234

\section{AWARDS}

\section{South African researchers awarded R220 million research grant}

The United States National Institutes for Health has announced the award of a major research grant to leading South African AIDS researchers. The $\$ 21.3$ million labout R220 million) award over 5 years will support HIVIAIDS research in a family setting, a rarely tried approach to fighting the disease. This grant is the largest yet made by the Comprehensive International Program for Research on AIDS (CIPRA). This national collaborative research effort will be led by Professor James McIntyre and co-ordinated by the Perinatal HIV Research Unit of the University of the Witwatersrand.

'Low-income households in South Africa carry the greatest burden of HIV/AIDS, experience the greatest negative effects, and have the least reserves to cope,' says Professor McIntyre. The new CIPRA grant, 'Safeguarding the Household: Comprehensive AIDS Research', will address HIV/AIDS as a problem not simply of individuals but of entire families, he explains, and all family members may participate in the studies. The cutting-edge research programme will focus on aspects of HIV treatment in adults and children, tuberculosis and affordable laboratory tests.

'This research agenda is of crucial importance to South Africa and our region. It will gather essential information for the government's AIDS programmes in the future, and covers many of the key areas raised in the recent cabinet statement on AIDS; explains Professor McIntyre. 'The grant award recognises the quality of South African AIDS research and will provide the opportunity to develop many more local researchers through an extensive, linked, training programme.'

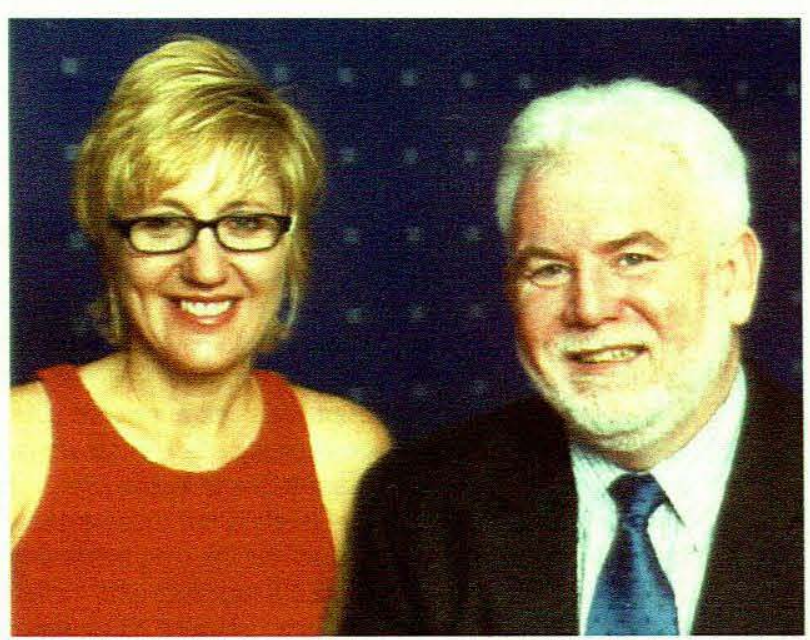

Professor James McIntyre and Glenda Gray, Executive Directors of the Perinatal HIV Research Unit, Chris Hani Baragwanath Hospital, Soweto.

The project will:

- Evaluate an affordable HIV/AIDS treatment programme for adults and children in a family setting at primary care level.

Test whether treatment interruption is an affordable and feasible way of controlling HIV infection in children that reduces the progression to AIDS.

Determine the efficacy of two standard childhood vaccines (used to prevent pneumonia and meningitis) in preventing AIDS-related complications in infants.

- Evaluate the community effect of highly active antiretroviral therapy on sickness and deaths due to AIDS and tuberculosis.

Develop simple, inexpensive methods of diagnosing HIV and monitoring treatment and drug resistance. 